\title{
Genetic Variation of Anatolian Black Pine (Pinus nigra Arnold. subsp. pallasiana (Lamb.) Holmboe) in the Lakes District of Turkey
}

\author{
By S. GÜLCÜำ and A. Ö. ÜÇLER ${ }^{2)}$
}

(Received $7^{\text {th }}$ April 2005)

\begin{abstract}
In this study, morphological characteristics of juvenile 1- and 2-year-old seedlings of Anatolian black pine were studied to estimate the amount of genetic variation and heritability of seedling traits of the species in the Lakes District of Turkey. This nursery study involved 460 parent trees from 23 populations in a randomized complete block design. Traits studied were the number and length of cotyledons, hypocotyls and epicotyls lengths, weight and length of initial roots, height, root collar diameter, and stem and root fresh weights, and number of buds. Variation was higher among than within populations with individual tree heritability ranging from 0.09 to 0.76 , whereas family mean heritability ranged from 0.16 to 0.80 . Genetic and phenotypic correlations between juvenile and 1-year-old seedling traits were generally the same sign and magnitude. Variation and heritabilities were higher for growth-related traits than the number and length of embryonic tissues. The observed level of population differentiation was low, possibly due limited geographic sampling of populations, which spanned only $2^{\circ}$ of latitudes and longitudes, and $300 \mathrm{~m}$ in elevation. If the observed heritabilities for growth traits were sustained to tree maturity combined family and within family selection would be effective in improving growth of this species in the Lakes District of Turkey. A broader geographic sampling is recommended for better estimation of population differentiation and establishment of the geographic pattern of the species in this region.
\end{abstract}

Key words: Pinus nigra, genetic variation, heritability, seedling traits.

\section{Introduction}

Black pine (Pinus nigra Arnold.) is one of the most widely distributed species of the Mediterranean basin, particularly in southern Europe and Anatolia. It occurs naturally as small clusters in Algeria and Morocco (DAVIS, 1965; KAYA and TEMERIT, 1993). Anatolian black pine [Pinus nigra Arnold. subsp. pallasiana (Lamb.) Holmboe] is one of the four recognized subspecies of black pine. It is native to a vast area extending from the Balkans to southern Carpathian Mountains, Crimea, Cyprus, Syria, Thrace and Anatolia (Alptekin, 1986). It occurs throughout Turkey except the northeast Black Sea region and covers the second largest area of all native commercial forest tree species of Turkey (YALTIRIK

\footnotetext{
1) Communicating author: Asst. Prof. Dr. SÜleyman GÜLCÜ, Suleyman Demirel University, Faculty of Forestry, 32260, Isparta, Turkey. Phone: +90 24621131 57. Fax: +90 246237 18 10. E-mail: sgulcu@orman.sdu.edu.tr

2) Prof. Dr. Ali ÖMER ÜÇLER, Karadeniz Technical University, Faculty of Forestry, 61080, Trabzon, Turkey. Phone: +90 462 37728 60. Fax: +90 46232574 99. E-mail: ucler@ktu.edu.tr
}

and EFE, 2000). Thus, Anatolian black pine is a high priority species in the National Forest Tree Breeding Programme in the country.

Subspecies pallasiana has been the most preferred black pine for reforestation in dry areas. However, some of reforestation with this species has failed possibly due to use of poorly adapted seed sources. Therefore, there is a need to study its genetic differentiation to facilitate proper allocation of seed sources to planting sites and obtain genetic parameters for tree breeding purposes.

In this study, we investigated genetic variation in seedling traits of black pine populations from the Turkey's Lakes District. Our objectives were to examine the distribution of genetic variation among and within populations, and estimate heritabilities for seedling traits during the first and second growing seasons.

\section{Materials and Methods \\ Populations and Parent Trees}

For this study, we used 460 open-pollinated families, 20 from each of 23 populations sampled from the Lakes District of Turkey. The sampled region lies between $36^{\circ}$ $52^{\prime}$ and $38^{\circ} 06^{\prime} \mathrm{N}, 29^{\circ} 22^{\prime}$ and $31^{\circ} 20^{\prime} \mathrm{E}$, and $1210-540$ meters above sea level. The families were sampled at random with the following restrictions; 1 ) they were to be separated by at least $150 \mathrm{~m}$ to minimize the rate of self-pollination, 2) the range of elevation of the families had to be not greater than $300 \mathrm{~m}$ within any one population, 3) they were to be approximately of the same age ( \pm 10 years), ranging from 70 to 80 years. Healthy cones from the last year crop were collected from the middle part of the crown. Cone collection and seed extraction was performed between December 1998 and February 1999.

\section{Experimental Design and Measurements}

Seeds were sown in five nursery beds in Eğirdir Forest Nursery (45 km northeast of Isparta, at $920 \mathrm{~m}$ above sea level) in April 1999. The layout of the experiment was a randomized complete block design with three replications and 7-seedling row plots. The spacing was 2 $\mathrm{cm}$ between seedlings within each row and $15 \mathrm{~cm}$ between rows. Seedlings were irrigated based on the operational regime for this nursery, but not fertilized and raised for two growing seasons in the nursery. The traits assessed are described as follows:

$$
\begin{aligned}
& \text { CN - Number of cotyledons } \\
& \text { CL - Length of cotyledons (mm) } \\
& \text { HL - Hypocotyl length }(\mathrm{mm}) \\
& \text { EP - Epicotyl length (mm) }
\end{aligned}
$$


$\mathrm{RL}$ - Radicular length ( $\mathrm{mm})$

RW - Radicular weight (g)

SW - Juvenile seedling weight (g)

H1 - Total seedling height at the end of the first growing season $(\mathrm{mm})$

H2 - Total seedling height at the end of the second growing season $(\mathrm{mm})$

RD1 - Total root collar diameter at the end of the first growing season $(\mathrm{mm})$

RD2 - Total root collar diameter at the end of the second growing season ( $\mathrm{mm}$ )

SW1 - Stem fresh weight at the end of the first growing season $(\mathrm{g})$

RW1 - Root fresh weight at the end of the first growing season $(\mathrm{g})$

BN2 - Number of buds on 2-year old seedlings

CN, CL, HL, EP, RL, RW, SW, H1, H2, RD1, RD2, SW1, RW1 and BN2 were measured on 10 seedlings from each replication at the end of the $8^{\text {th }}$ week from germination before secondary leaves started to grow. Similarly, at the end of first and second growing seasons, another 10 seedlings were collected from each replication for each family (totally 30 seedlings) and measured for 1- and 2-year-old seedling traits.

\section{Data Analyses}

Before performing the analysis, data were examined for conformity to the normal distribution and homogeneity of the variance assumptions. The outliers were removed from the data. The number of cotyledons $(\mathrm{CN})$ and buds (BN2) significantly deviated from these assumptions. Therefore, the data of these traits were square root-transformed before analysis. All other traits were analyzed without transformation. ANOVA for all traits used the following statistical model:

$$
\begin{aligned}
Y_{i j k m}= & \mu+R_{i}+P_{j}+F(P)_{k(j)}+ \\
& R P_{i j}+R F(P)_{i k(j)}+e_{m(i j k)}
\end{aligned}
$$

Where;

$\mathrm{Y}_{\mathrm{ijkm}}$ is the measurement on the $m^{\text {th }}$ seedling of the $k^{\text {th }}$ family from the $j^{\text {th }}$ population in the $i^{\text {th }}$ replication; $\mu$ is the overall mean; $\mathrm{R}_{\mathrm{i}}$ is the effect of $i^{\text {th }}$ replication $(\mathrm{i}=1$, $2,3) ; \mathrm{P}_{\mathrm{j}}$ is the effect of $j^{\text {th }}$ population $(\mathrm{j}=1,2,3, \ldots, 23)$; $\mathrm{F}(\mathrm{P})_{\mathrm{k}(\mathrm{j})}$ is the effect of $k^{\text {th }}$ family in $j^{\text {th }}$ population $(\mathrm{k}=1$, $2,3, \ldots, 20) ; \mathrm{RP}_{\mathrm{ij}}$ is the interaction effect between $i^{\text {th }}$ replications and $j^{\text {th }}$ populations; $\mathrm{RF}(\mathrm{P})_{\mathrm{ik}(\mathrm{j})}$ is the interaction between $i^{\text {th }}$ replications and $k^{\text {th }}$ family within $j^{\text {th }}$ population; $\mathrm{e}_{\mathrm{m}(\mathrm{ijk})}$ is the residual. Except $\mu$, all effects on the right side of the model were considered random with zero expectation and respective variances. The restricted maximum likelihood estimates of variance components were calculated using PROC MIXED (SAS INST. INC., 1988). In addition, the SAS PROC GLM was used to obtain the coefficients of the expected mean squares for calculation of heritabilities.

Heritabilities were estimated from the variance components as described in SHELBOURNE (1969; 1992) and FALCONER and MACKAY (1996). Individual tree and family mean heritabilities for each trait were estimated using equation 2 and 3 , respectively.

$$
h_{i}^{2}=\frac{\sigma_{A}^{2}}{\sigma_{U}^{2}}=\frac{4 \sigma_{F(P)}^{2}}{\sigma_{U}^{2}}
$$

Where $h^{2}{ }_{i}=$ individual tree heritability, $\sigma_{A}^{2}=$ additive genetic variance, $\sigma_{F(P)}^{2}=$ between-family-within-population variance component, and $\sigma^{2}{ }_{U}=$ phenotypic variance calculated as, $\sigma_{U}^{2}=\sigma_{F(P)}^{2}+\sigma_{R F(P)}^{2}+\sigma_{e}^{2}$, where $\sigma_{F(P)}^{2}=$ variance due to interaction between replication and family-within-population (experimental error) and $\sigma^{2}{ }_{e}=$ variance among individual trees within family (sampling error).

$$
h_{f}^{2}=\frac{\sigma_{F(P)}^{2}}{\sigma_{f m}^{2}}
$$

Where $h_{f}^{2}=$ family mean heritability and $\sigma^{2}{ }_{f m}=$ family phenotypic variance, calculated as $\sigma_{f m}^{2}=\sigma_{F(P)}^{2}+\left(k_{2} / k_{3}\right)$ $\sigma_{R F(P)}^{2}+\left(1 / k_{3}\right) \sigma_{e}^{2}$, where $k_{2}$ and $k_{3}$ are, respectively, coefficients for $\sigma_{R F(P)}^{2}$ and $\sigma_{F(P)}^{2}$ in the expected mean squares.

Genetic correlations were estimated from the component of variance and covariance (FALCONER, 1981) substituted into the standard equation for the product moment correlation coefficient.

$$
R g_{(x, y)}=\frac{\operatorname{COV}_{f(x, y)}}{\sqrt{\sigma_{f(x)}^{2}} \sqrt{\sigma_{f(y)}^{2}}}
$$

Where $R g_{(x, y)}=$ estimated genetic correlation between traits $x$ and $y, \sigma_{f(x)}^{2}=$ estimated components of variance of families within populations for trait $x, \sigma_{f(y)}^{2}=$ estimated components of variance of families within populations for trait $y$, and $C O V_{f(x, y)}=$ estimated component of covariance of families within populations between traits $x$ and $y$, estimated from covariance analysis.

The phenotypic correlation between traits $x$ and $y$ were calculated from family mean squares and mean cross products for the traits according to KAYA et al. (1989).

\section{Results and Discussion}

There was significant $(\mathrm{P} \leq 0.05)$ variation among populations for CN, HL, RL, RW, SW, H1, RD1, H2 and RD2 but not CL, EL, SW1, RW1 and BN2 (Table 1). The component of the total variance attributed to variation among populations was less than $5 \%$, except for RW $(6.6 \%)$. On the other hand, families within populations showed significant variation for all traits. The components of the total variance attributed to variation among families within populations ranged from $1.7 \%$ in HL to $19 \%$ in SW1 (Table 1).

Table 1 shows that CN, CL, HL, EL, RL and RW exhibited low $h^{2}{ }_{i}(0.09-0.26)$ and $h_{f}^{2}(0.16-0.42)$, compared to traits measured at the end of the first and second growing seasons where $h^{2}$ and $h^{2}$ were $0.34-0.76$ and $0.65-0.80$, respectively (Table 1 ). The values of phenotypic and genetic correlations between juvenile and 1year-old seedling traits were generally the same sign and magnitude (Table 2). Thus, only genetic correlation between traits will be reported. Genetic correlations between total root collar diameter (RD1) and total 
Table 1. - Components of total variance (\%) and heritability estimates for seedling traits of Anatolian Black Pine.

\begin{tabular}{llllllllll}
\hline Traits & $\bar{x} \pm \mathrm{SE}$ & $\sigma_{R}^{2}$ & $\sigma_{P}^{2}$ & $\sigma_{R P}^{2}$ & $\sigma_{F(P)}^{2}$ & $\sigma_{R F(P)}^{2}$ & $\sigma_{e}^{2}$ & $h_{i}^{2}$ & $h_{f}^{2}$ \\
\hline CN & $9.0 \pm 1.70 \mathrm{E}-03$ & $0.0^{* * *}$ & $0.0^{*}$ & $0.0 \mathrm{~ns}$ & $3.8^{* * *}$ & $3.4^{* * *}$ & 92.1 & $0.15 \pm 0.04$ & $0.39 \pm 0.07$ \\
CL & $31.0 \pm 4.99 \mathrm{E}-03$ & $1.0^{* * *}$ & $0.2 \mathrm{~ns}$ & $0.3 \mathrm{~ns}$ & $6.4^{* * *}$ & $14.3^{* * *}$ & 77.9 & $0.26 \pm 0.05$ & $0.42 \pm 0.08$ \\
HL & $16.6 \pm 3.41 \mathrm{E}-03$ & $10.7^{* * *}$ & $1.4^{* * *}$ & $0.2 \mathrm{~ns}$ & $1.7^{*}$ & $15.6^{* * *}$ & 70.5 & $0.08 \pm 0.04$ & $0.16 \pm 0.07$ \\
EL & $10.2 \pm 2.91 \mathrm{E}-03$ & $7.6^{* * *}$ & $0.0 \mathrm{~ns}$ & $0.0 \mathrm{~ns}$ & $2.2^{* *}$ & $23.7^{* * *}$ & 66.4 & $0.09 \pm 0.05$ & $0.16 \pm 0.08$ \\
RL & $214.5 \pm 3.92 \mathrm{E}-02$ & $0.1^{*}$ & $0.2^{*}$ & $0.3 \mathrm{~ns}$ & $2.4^{* * *}$ & $9.0^{* * *}$ & 88.0 & $0.09 \pm 0.03$ & $0.24 \pm 0.08$ \\
RW & $0.3 \pm 2.19 \mathrm{E}-03$ & $0.0 \mathrm{~ns}$ & $6.6^{* * *}$ & $0.0 \mathrm{~ns}$ & $2.4^{* * *}$ & $5.4^{* * *}$ & 84.9 & $0.10 \pm 0.03$ & $0.29 \pm 0.08$ \\
SW & $0.7 \pm 2.82 \mathrm{E}-03$ & $1.1^{* * *}$ & $1.4^{* * *}$ & $0.0 \mathrm{~ns}$ & $5.1^{* * *}$ & $10.4^{* * *}$ & 81.9 & $0.21 \pm 0.04$ & $0.40 \pm 0.07$ \\
H1 & $33.8 \pm 7.61 \mathrm{E}-03$ & $0.1^{* *}$ & $1.5^{* * *}$ & $0.1 \mathrm{~ns}$ & $13.1^{* * *}$ & $1.1^{* * *}$ & 84.1 & $0.53 \pm 0.05$ & $0.74 \pm 0.07$ \\
RD1 & $1.5 \pm 3.22 \mathrm{E}-03$ & $0.4^{* * *}$ & $0.7^{*}$ & $0.4^{*}$ & $16.8^{* * *}$ & $3.2^{* * *}$ & 78.4 & $0.68 \pm 0.06$ & $0.77 \pm 0.07$ \\
SW1 & $0.6 \pm 2.66 \mathrm{E}-03$ & $0.0^{* *}$ & $0.4 \mathrm{~ns}$ & $0.0 \mathrm{~ns}$ & $19.0^{* * *}$ & $2.4^{* * *}$ & 78.3 & $0.76 \pm 0.06$ & $0.78 \pm 0.07$ \\
RW1 & $0.6 \pm 2.36 \mathrm{E}-03$ & $0.0^{*}$ & $0.0 \mathrm{~ns}$ & $0.0 \mathrm{~ns}$ & $12.2^{* * *}$ & $1.9^{* * *}$ & 86.0 & $0.49 \pm 0.05$ & $0.71 \pm 0.06$ \\
H2 & $88.4 \pm 2.38 \mathrm{E}-02$ & $0.0 \mathrm{~ns}$ & $4.3^{* * *}$ & $0.0 \mathrm{~ns}$ & $16.7^{* * *}$ & $0.9^{* * *}$ & 78.0 & $0.70 \pm 0.06$ & $0.80 \pm 0.07$ \\
RD2 & $3.3 \pm 8.96 \mathrm{E}-03$ & $0.0 \mathrm{~ns}$ & $3.2^{* * *}$ & $0.2 \mathrm{~ns}$ & $14.7^{* * *}$ & $2.0^{* * *}$ & 80.0 & $0.61 \pm 0.05$ & $0.76 \pm 0.07$ \\
BN2 & $3.0 \pm 3.22 \mathrm{E}-03$ & $0.0^{*}$ & $0.2 \mathrm{~ns}$ & $0.0 \mathrm{~ns}$ & $8.7^{* * *}$ & $1.2^{*}$ & 89.9 & $0.34 \pm 0.04$ & $0.65 \pm 0.07$ \\
\hline
\end{tabular}

$\bar{x} \pm \mathrm{SE}:$ means and standard errors.

$\sigma_{R}^{2}: \quad$ Estimated variance components of replications,

$\sigma^{2}{ }_{p}: \quad$ Estimated variance components of populations,

$\sigma^{2}{ }_{R P}:$ Estimated variance components due to interaction between replications and populations,

$\sigma_{F(P)}^{2}$ : Estimated variance components of families within populations,

$\sigma^{2}{ }_{R F(P)}$ : Estimated variance components due to interaction between replications and families,

$\sigma^{2}:$ Estimated variance components of individuals within families,

$\mathrm{h}^{e^{e^{*}}}=$ Individual heritability,

$\mathrm{h}_{\mathrm{f}}^{\mathrm{i}}=$ family heritability,

ns: none significant; *: significant at $\mathrm{P}<0.05$; **: significant at $\mathrm{P}<0.01$; ***: significant at $\mathrm{P}<0.001$.

Table 2. - Genetic (below diagonal) and phenotypic (above diagonal) correlations between traits.

\begin{tabular}{lllllll}
\hline Traits & CN & EL & H1 & RD1 & H2 & RD2 \\
\hline CN & - & $0,13^{* *}$ & $0,05 \mathrm{~ns}$ & $0,10^{*}$ & $0,09 \mathrm{~ns}$ & $0,10^{*}$ \\
EL & 0,15 & - & $0,27^{* *}$ & $0,14^{* *}$ & $0,14^{* *}$ & $0,20^{*}$ \\
H1 & 0,01 & 0,27 & - & $0,27^{* *}$ & $0,10^{*}$ & $0,09 \mathrm{~ns}$ \\
RD1 & 0,17 & 0,18 & 0,28 & - & $0,08 \mathrm{~ns}$ & $0,14^{* *}$ \\
H2 & 0,08 & 0,04 & 0,04 & 0,05 & - & $0,42^{* *}$ \\
RD2 & 0,15 & 0,14 & 0,01 & 0,11 & 0,29 & - \\
\hline
\end{tabular}

Note: 460 open pollinated families involved in estimation of phenotypic and genetic correlations. ns: none significant; *: significant at $\mathrm{P}<0.05$; **: significant at $\mathrm{P}<0.01$.

seedling height $(\mathrm{H} 1)$ in the first growing season were strong (0.28) and the same those between total root collar diameter (RD2) and total seedling height (H2) in the second growing season. Genetic correlations between RD1 and RD2 were strong (0.11) and higher than those between $\mathrm{H} 1$ and $\mathrm{H} 2$ (0.04). In addition genetic correlations between CN-RD1 and CN-RD2 were stronger (0.17 and 0.15 respectively) than those between $\mathrm{CN}-\mathrm{H} 1$ and CN-H2 (0.01 and 0.08 respectively). That is, families with a greater number of cotyledon had greater root collar diameter in the first and second growing season. The presence of weak genetic correlations between $\mathrm{CN}-\mathrm{H} 1$ and $\mathrm{CN}-\mathrm{H} 2$ in the first and second growing season will also increase the efficiency selection of within population for height increment. On the other hand, the existence of strong genetic correlations between CN-RD1 and CN-RD2 make height growth a unique choice for further genetic studies in this species.

This investigation revealed that the populations sampled from Turkey's Lakes District were genetically variable and a greater amount of genetic variation resided within populations. The populations involved in this study spanned only $2^{\circ}$ of latitude and longitude, and 300 $\mathrm{m}$ in elevation. This limited geographic sampling could account for a low level $(<5 \%)$ of genetic variation among populations observed in this study. Studies of black pine and other conifers have shown that species with wide natural geographic ranges exhibit low genetic variation among populations but high within the populations (TOLUn et al., 2000; ÇENGEL et al., 2000; KAYA et al., 2003). Thus, Anatolian black pine would be no exception. High within-population genetic variation and heritability observed in this study could partly be due to maternal effect, especially seed size, because morphological and growth-related traits studied were assessed on very young seedlings (KAYA and TEMERIT, 1994). Nevertheless, observation of higher within-population than between-population genetic variability in Anatolian black pine is consistent with results of studies of other forest tree species (BONGARTEN and HANOVER, 1986; MATZIRIS, 1989, 1993; BURDON et al., 1992; LI et al., 1993; LEE et al., 2007).

High heritabilities for growth-related traits (e.g., H1 and H2) support results of earlier studies of Anatolian 
black pine populations (KAYA and TEMERIT, 1993, 1994; VELIOGLU et al., 1999) in which family mean heritabilities were $0.28-0.98$. If these high heritabilities were maintained to tree maturity, a combination of family and within-family selection would be effective in improving growth of Anatolian black pine population in the Lake District of Turkey.

Because of limited geographic sampling, only low genetic variation among populations was observed. Future studies of this species should broaden the geographic range of populations to be tested and established the pattern of variation in relation to geographic and climatic variables. Many studies of conifers have shown that population differentiation is related to climate and ecology of seed origin (YEATMAN, 1966; GUINON et al., 1982; HAWKINs et al., 1991; ADAMs et al., 2007). Only in the way we will be able to match Anatolian black pine populations in the Lake District of Turkey to appropriate planting cites for tree improvement and reforestation.

\section{Conclusions}

In this study, levels of genetic diversity in Anatolian Black Pine were found to be higher for all traits within populations than among them. Based on these results, it may be appropriate to use well performing populations of this subspecies as seed sources for reforestation and regeneration practices in the Lakes District. However, genetic diversity within these populations should be well represented by including as many distantly related parent trees as possible. Furthermore, additional field trials should be conducted prior to large-scale use of these populations to see if they can in fact perform well in the field.

Large within population genetic variation is also reflected by the estimated family heritabilities. Family heritabilities for the traits of juvenile, one and two-yearold seedlings suggest that selection within populations will yield rapid genetic improvement. It is likely that selection within populations will be much more effective than selection between populations.

The results of this study represent only the populations of Lakes District. Therefore, considering that the range of Anatolian Black Pine covers large and diverse areas in Turkey, further studies, which will explore the genetic diversity of all possible populations, are needed to better understand the genetic variation in this subspecies.

\section{Acknowledgements}

We are grateful to anonymous reviewers for their valuable comments on the manuscript. We are also thankful to Dr. Alistair S. Jump, Dr. FikRet IsiK and Dr. NevZat GURLEVIK for their advice and checking over the manuscript in terms of both English and scientific content. Thanks are also to RUmi SABUncU, SEmRA Keskin for the technical help and their institution for the permission to use their SAS statistical software during the data analysis. This study was financially granted by Black Sea Technical University (Project: AFP-99.113.001-5).

\section{References}

Adams, J. P., R. J. Rousseau and J. C. Adams (2007): Genetic Performance and Maximizing Genetic Gain Through Direct and Indirect Selection in Cherrybark Oak, Silvae Genetica 56: 80-87.

ALPTEKIN, C. U. (1986): Anadolu Karaçamı'nın (Pinus nigra ssp. pallasiana Lamb. Holmboe) Coğrafik Varyasyonları, İ̈̈ Orman Fakültesi Dergisi A. 36: 132-154.

Bongarten, B. C. and J. W. Hanover (1986): Genetic Parameters of Blu Spruce (Picea pungens) at Two Locations in Michigan, Silvae Genetica 35: 106-112.

Burdon, R. D., M. H. Bannister and C. B. Low (1992): Genetic Survey of Pinus radiata, 3: Variance Structures and Narrow-Sense Heritabilies for Growth Variables and Morphological Traits in Seedlings, New Zealand Journal of Forestry Science 22: 160-186.

Çengel, B., E. VelioĞLu, A. A. Tolun and Z. KAYA (2000): Pattern and Magnitude of Genetic Diversity in Pinus nigra ARNOLD subspecies pallasiana Populations from Kazdağ1: Implications for in situ Consevation, Silvae Genetica 49: 249-256.

Davis, P. H. (1965): Flora of Turkey and the East Aegeand Islands, Vol: 1, at the University Press, Edinburg.

FALCONER, D. S. (1981): Introduction to Quantitative Genetics, $2^{\text {nd }}$ Edition, Longman Inc., New York.

FALCONER, D. S. and T. F. C. MACKAY (1996): Introduction to Quantitative Genetics, 2 ${ }^{\text {nd }}$ Edition. Longman Inc. Group U.K. Limited, $4^{\text {th }}$ Edition.

Guinon, M., J. B. LARSEN and W. Spethmann (1982): Frost Resistance and Early Growth of Sequoiadendron giganteum Seedlings of Different Origins, Silvae Genetica 31: 173-178.

Hawkins, B. J., G. B. Sweet, D. H. Greer and D. O. BERGIN (1991): Genetic Variation in the Frost Hardiness of Podocarpus totara, New Zealand Journal of Botany 29: $455-458$.

KaYA, Z., R. K. CAmpbell and W. T. AdAms (1989): Correlated Responses of Height Increment and Components of Increment in 2-year-old Douglas-fir Seedlings, Can. J. For. Res. 19: 1124-1130.

KayA, Z. and A. Temerit (1993): The Magnitude and Pattern of Genetic Variation in European Black Pine (Pinus nigra var. pallasiana) Populations in Turkey, Doğa, Turkish Journal of Agriculture and Forestry, Ankara 17: 267-279.

KAYA, Z. and A. TEMERIT (1994): Genetic Structure of Marginally Located Pinus nigra var. pallasiana Populations in Central Turkey, Silvae Genetica 43: 272-277.

Kaya, Z., F. Steel, A. Temerit and H. Vurdu (2003): Genetic Variation in Wood Specific Gravity of Half-sib Families of Pinus nigra subsp. pallasiana Tested at the Juvenile Stage: Implications for Early Selection, Silvae Genetica 52: 153-158.

LeE, S. J., J. Woolliams, C. J. A. SAmuel and D. C. MalCOLM (2007): A study of Population Variation and Inheritance in Sitka Spruce, IV: Correlated response in the progeny population based on selection in the parental population, Silvae Genetica 56: 36-44.

Li, P., J. Beaulieu, A. Corriveau and J. Bousquet (1993): Genetic Variation in Juvenile Growth and Phenology in a White Spruce Provenance-Progeny Test, Silvae Genetica 42: 52-60.

MatziRIS, D. I. (1989): Variation in Growth and Branching Characters in Black Pine (Pinus nigra Arnold.) of Peloponnesos, Silvae Genetica 38: 77-81. 
MatZIRIS, D. (1993): Variation in Cone Production in a Clonal Seed Orchard of Black Pine, Silvae Genetica 42: 136-141.

SAS Inst. Inc. (1988): SAS/STAT User's Guide, Release 6.03 Edition, Cary, NC.

Shelbourne, C. J. A. (1969): Tree Breeding Methods. New Zealand Forest Research Institute, Technical Paper No: 55, ODC: 165. 3/7, New Zealand.

ShelbouRNE, C. J. A. (1992): Genetic Gains from Different Kinds of Breeding Population and Seed or Plant Production Population, Paper Presented at the IUFRO Symposium "Intensive Forestry: The Rule of Eucalyptus", Held in Durban, South Africa, in September 1991: 49-65.

Tolun, A. A., E. VelioĞLu, B. (Nazlier) Çengel and Z. KAYA (2000): Genetic Structure of Black Pine (Pinus nigra ARNOLD subspecies pallasiana) Populations Sampled from the Bolkar Mountains, Silvae Genetica 49: 113-119.

VELIOĞLU, E., B. ÇENGEL and Z. KAYA (1999): Genetic Variation in Natural Black Pine (Pinus nigra Arnold. susp. pallasiana (Lamb.) Holmboe.) Populations Sampled from Kazdağlari, Forest Tree Seeds and Tree Breeding Research Directorate, Technical Bulletin No: 1, Ankara.

YAltiRIK, F. and A. EFE (2000): Dendroloji Ders Kitabı, İÜ Yayın No 4265, OF Yayın No 465, İstanbul.

Yeatman, C. W. (1966): Joint Proceedings of the Second Genetics Workshop of the Society of American Foresters and the Seventh Lake States Forest Tree Improvement Conference; Res. Pap. NC-6. St. Paul, MN: U.S. Department of Agriculture, Forest Service, North Central Forest Experiment Station: 28-36.

\title{
Chromosomal Mapping of 18S-25S and 5S Ribosomal Genes on 15 Species of Fagaceae From Northern Thailand
}

\author{
By P. Chokchaichamnankit ${ }^{1,2)}$, K. Anamthawat-Jónsson ${ }^{2)}$ and W. Chulalaksananukul ${ }^{\left.1),{ }^{*}\right)}$
}

(Received $5^{\text {th }}$ July 2006)

\begin{abstract}
Fifteen species of Fagaceae from Chiang Mai province, northern Thailand, were investigated: eight Castanopsis, four Lithocarpus and three Quercus species. The species were generally diploid with the chromosome number $2 \mathrm{n}=24$, and the basic number $\mathrm{x}=12$ was confirmed in some species with meiosis. One tree belonging to $Q$. lenticellatus had $2 \mathrm{n}=14$. Chromosomal mapping of the highly repetitive $18 \mathrm{~S}-25 \mathrm{~S}$ and $5 \mathrm{~S}$ ribosomal genes by fluorescence in situ hybridisation (FISH) was performed. Most species (from all three genera) showed four 18S-25S rDNA sites (two pairs: one subterminal major and one paracentromeric/intercalary minor loci) and two 5S rDNA sites (one pair: paracentromeric locus). Quercus kerrii also had two pairs of 18S-25S rDNA sites, but both were subterminal major loci. Two species, $C$. argentea and $Q$. brandisianus, only had one pair of 18S-25S rDNA sites. Two species, C. calathiformis and $L$. vestitus, showed an odd number of (unpaired) sites, and this indicated hybrid origin and/or polyploidy. Polyploid cells were detected in these species. The ribosomal gene maps based on both sequences together were genus-specific. In Castanopsis, the 18S-25S and the $5 \mathrm{~S}$ genes were localized on three different chromosome pairs, and comprised species-specific maps. On the other hand, the

1) Department of Botany, Faculty of Sciences, Chulalongkorn University, Phayathai Road, Bangkok 10330, Thailand.

$\left.{ }^{2}\right)$ Biology Institute, University of Iceland, Askja - Sturlugata 7, Reykjavik IS-101, Iceland.

*) Corresponding author: Department of Botany, Faculty of Sciences, Chulalongkorn University, Phayathai Road, Bangkok 10330, Thailand. Tel: +66 22185482 ; Fax: +66 22185482 ; Email: warawut.c@chula.ac.th
\end{abstract}

ribosomal genes in Lithocarpus and Quercus were found only on two chromosome pairs, because one of the two $18 \mathrm{~S}-25 \mathrm{~S}$ rDNA loci was localized on the same chromosome as the 5S rDNA locus. The FISH markers may be used to clarify discrepancies arising from morphological assessments.

Key words: Fagaceae, Castanopsis, Lithocarpus, Quercus, fluorescence in situ hybridisation (FISH), ribosomal gene mapping, 18S-25S and 5S rRNA genes.

\section{Introduction}

Fagaceae (beech family) includes 7-12 genera and 600-1000 species distributed worldwide, apart from tropical and southern Africa (SoEPADMO, 1972; SCOGGAN, 1978; ChenguIU et al., 1999). Fagaceae dominates forests in the temperate, seasonally dry regions of the Northern Hemisphere, with a centre of diversity found in tropical South-east Asia (SoEPADMO, 1972; MANos et al., 2001). In Thailand (FORMAN, 1964; GARDNER et al., 2000; PhengKLAI et al., 2005), this family comprises four genera: Castanopsis (D. Don) Spach. (chestnut, mostly evergreen, 33 species); Lithocarpus Blume (stone oak, mostly evergreen, 56 species); Quercus L. (oak, mostly deciduous, 29 species); and Trigonobalanus Forman (evergreen, one species). SoEPADMO (1972) emphasized that South-east Asia, Indo-China in particular, maintained the greatest assemblage and most primitive forms of Castanopsis and Lithocarpus as well as Quercus (subgenus Cyclobalanopsis), compared to other regions of the world. Many of these species, especially in the genus Castanopsis, form part of the montane forest distribution east of Himalaya, including eastern Nepal, 